\title{
The Impact of Rural Saving and Credit Cooperative on Multidimensional Poverty Status: Evidence from Rular Households in Awabel District, Amhara Region, Ethiopia
}

\author{
YESHIWAS EWINETU TEGEGNE \\ Debre Markos University, Debre Markos ,Ethiopia
}

\begin{abstract}
Multidimensional poverty is the problem of every country in the world; hence, it needs the attention of policy makers and various development actors like cooperatives. The main purpose of this study is to investigate the impact of saving and credit cooperative financial service on multidimensional poverty status of rural household in Awabel district. The specific objectives of the study is to examine the impact of saving and credit cooperative financial service on multidimensional poverty status of rural households, to identify determinants of multidimensional poverty status of rural households, to identify the dimension of household poverty affected by saving and credit cooperatives financial services. The study adopts a cross sectional, and quantitative research design. The target population was 4,675 actively registered RuSACCO members' households. The sample size was a total of 380 i.e190 members as a treated group and 190 nonmembers as counterfactual obtained through multi-stage sampling techniques .The data is primary data collected through household survey.For data analysis firstly, binary logit models is used to identify the determinants of multidimensional poverty status of rural households; and the finding revealed multidimensional poverty status of rural household has negative relationship between RuSACCO membership status (-4.2\%), size of cultivated landholdings $(-5 \%)$, access for agricultural extension service (-4.01\%), and access for road (-1.7\%) and are all statistically significant at $1 \%$ level. Moreover, there was a negative relationship between experience of household head on agricultural activity $(-0.15 \%)$ and statistically significant at $5 \%$ level, the risen in educational status of household head from illiterate to literate, primary to secondary and from secondary to higher education goes dawn multidimensional poverty status by-1.8\%, $-3 \%$ and $-4.3 \%$ and all are statistically significance at $1 \%$ level It is also found that, there were positive relationship between, multidimensional poverty status of rural households and dependency ratio $(0.11 \%)$ at $5 \%$ level of significance) in Awabel district. Secondly ,propensity score match model is applied to examine the impact of RuSACCO financial service on multidimensional poverty status of rural households, and the finding revealed that, financial service of RuSACCO had reduce the multidimensional poverty index of rural household by 0.082898018 on average for members. The findings also showed that the RuSACCOs financial service has reduced health dimension of poverty by 0.036242775 , the educational dimension of poverty by 0.018915905 standard of living dimension of poverty by 0.0152 , on average for RuSACCO members compare to that of non members. It is recommended the government should give special attention for organization and promotion of cooperative. Cooperative extension workers should advice members of RuSACCO to spend their financial service on health, education and standard of livings respectively. Increase productivity per size of cultivated landholding, work hard to bring literate farmers, work against reducing young age dependency, rising road accessibility, increase the accessibility of agricultural extension workers, and experience sharing among farmers to reduce the multidimensional status of rural household's members in Awabe district.
\end{abstract}

Keywords: RuSACCOs financial service, Multidimensional poverty, Awabel district in Amahara region, propensity score matching model.

DOI: $10.7176 / \mathrm{DCS} / 9-9-02$

Publication date:September $30^{\text {th }} 2019$

\section{Background of the study}

There are a total of 1.45 billion (76\%)people are multidimensional poor from 103 poor countries i.e $26.50 \%$ of people live in these countries, $36 \%$ of people live is Sub-Sahara Africa. When multidimensional poverty index(MPI) and its indicators are disaggregated by 988 sub-national region in 78 countries, Specifically, multidimensional poverty index of rural Ethiopia is still sever having MPI 0.637(from the total MPI 0.564) in year 2017. particularly,Amhara region had MPI of 0.58, head count ratio $90.1 \%$ and intensity of poverty $(65.2 \%)$ hence, multidimensional aspect of poverty is relevant to rural Amhara region. The poor in rural area of Ethiopia not only having low level of income; they are also poor in health, education and standard of livings ((OPHI), 2017).

Alleviation of poverty has become the biggest challenge to human society. In response the global Campaign has gained momentum with various development actors suggesting the uses of different instrument to alleviate poverty .There is an emerging consensus among many actors such as United nation (UN), International Labuor Organization (ILO), the European Union (EU) and International Cooperative Alliance (ICA) Cooperative society is one of the few forms of organization that can meet all dimension of poverty. Saving and credit cooperative 
(SACCO) have proved the possibility of providing reliable service to the poor customers which ultimately aim of reducing poverty ((WB), 2007).

Saving and credit cooperative is a powerful strategy or instrument, among several others, for alleviating poverty in general and rural poverty in particular in developing countries. It is also argued that most of the rural people are depending on non-formal financial institutions and private money lenders for getting financial assistance. Additionally, they have been paying high interest rate for their loan amount (MuthyaluMeniga,2014).

Poverty reduction activates of saving and credit cooperative on member have support the development of a community; through vocational skill training, educational empowerment, social protection and financial support to members. Such supports in turn enable the members to be self-reliant, participant in decision making and resource mobilization (Adekola, G. and Dokubo,Chidinma , 2017).

For the last ten year there has been progress on the growth of RuSACCO in Ethiopia due to the progarmme support of Rural Financial Intermediation Program (RUFIP), co-financed by International Fund for Agricultural Development (IFAD) and African Development Bank (ADB) and a multi-donor programmer called Household Asset Building Programme. RUFP in Ethiopia was to enhance poor rural people's access to regular and reliable financial services so that they may, inter alia, adopt improved agricultural production technologies and undertake off-farm and non-farm income-generating activities with a view to improving food security and family incomes (IFAD, 2011).The International Fund for Agricultural Development (IFAD), a specialized agency of the United Nations, was established as an international financial institution in 1977 which is dedicated to eradicating rural poverty in developing countries by increasing rural poor peoples' access to financial services, markets, technology, land and other natural resources.

Following this actions taken by the government of Ethiopia until 2016 there are a total number of 18,959 primary saving and credit cooperatives in Ethiopia of which the largest three regions; 7933, 4238 and 3050 were found Oromo, Southern nation and nationality Amahara regional state respectively. Totally 2,010,759 number of peoples were member of saving and credit cooperatives of which 1,791,222 were female and the remaining 380,198 were female having birr 7, 246,142,467 amount of saving and birr 3,658,974,306 amount of capital ((FDRE) cooprative proclamation no 147/98, 1998,2016).However, despite considerable efforts were made through poverty alleviation programs wide spread socio and economic poverty remain core problem in rural Ethiopia since its economy predominantly agriculture ((OPHI), 2017).Moreover, poverty level and SACCO services change continuously and therefore a lot remains to be desired (Eleuter Atilio Kihwele and Raphael Gwahula , 2015). Additionally, the global MPI data did not decompose the poverty level at zone, district and sub district level in one side and it is an aggregated data which did not show the poverty level between members of RuSACCO and poverty level of non-members on the other side for a given country. Cognizing this fact, the researcher is interested to investigate the impact of rural saving and credit cooperative to multidimensional poverty status of beneficiaries households compare to that of non-beneficiaries households in Awabel district.

\subsection{Statement of the Problem}

Saving and credit cooperative perform different activates in the provision of financial and non-financial activates such as provide divided on share, investment opportunity ,saving and credit service, training on entrepreneurial skills which in turn improve the living condition of farmers and their by reduce income poverty status of members (Melania D.Kawi and Justin K.Urassa, 2015).

Saving and credit cooperative loan service have strong impact for poverty reduction through increase in income, social service and creating self -employment opportunity given the loan are invested in income generating activity. Its service on providing entrepreneurial skill was very small rate and the training provided create awareness on the term and condition of loans and saving but not creating business skill (Eleuter Atilio Kihwele and Raphael Gwahula , 2015). It is also argued that SACCO'S financial services smooth consumption over time preventing undernourishment in the face of shocks, and reduces general undernourishment through investments in productivity enhancing equipment (Claessens, 2007) .

SACCOS have played minimal role towards promoting rural livelihoods in Makungu ward Iringa Tanzania the feature that made poverty situation to persist to the community members ( (Churk, 2015 ). It is also found that the contribution of SACCO to promote the growth and suitability of small business is poor due the combined challenges of high interest rate charge on members, absence of seminar and training to the business proprietors ( (Obadia, 2014).

SACCOS in Ethiopia are playing an active role both in rural and urban areas. Their number has increased from 5,437 in 2006 to 14,453 in May 2014 showing a compound growth rate of 28\% per year. It was identified that the absence of financial cooperatives policy and regulatory environment, weak institutional capacity, narrow product range and inappropriate loan security requirements as challenges for SACC (Kifle, 2015).

It is pointed out that SACCO service help to meet consumption need, pay school fees, run small business ,increase and diversify the income which is useful for poverty reduction given how the loan are used( (Ahlén, 2012). The promotion of these community-based microfinance groups leads to an improvement in 
household business outcomes and women's empowerment. However, they did not find evidence of impact on average consumption (Dean Karlan,etal ,2017).

The contribution of SACCOS to promote the growth and suitability of small business is poor due the combined challenges of high interest rate charge on members, absence of seminar and training to the business proprietors (Obadia,2014)2014;(Oluoch,2016).

Saving and credit cooperative loan service and participation have had no significant impact on annual house hold income, saving and asset acquisition ((Antawi, 2015)).

Even though, the above research were conducted indifferent countries of the world on the impact of saving and credit cooperative on poverty reduction they found mixed result and most of their study were focus on income poverty reduction role SACCO at house hold level and did not show multidimensional aspects of poverty in three dimension and ten indicators. Cognizing this inconclusive findings the researcher is interested to investigate the extent of rural saving and credit cooperative financial service for its members multidimensional poverty status at household level in Awabel district to partial fill the existing literature Gap. Additionally, there is institutional and location difference across these countries and hence, the impact had difference from one SACCOS to another SACCO. Because of this, the researcher is initiated to analyze the impact of RuSACCO on multidimensional poverty status of household's of Awabel district. Moreover, for the last five year the numbers of primary saving and credit cooperative members rise from 340,655 to 706,316 from year 2011 to 2016. The expansion of saving and credit cooperative society is higher in rural area than urban area of Ethiopia. Taking the data of 2016 there were a total of 18,959 numbers of primary saving and credit.From these total 14,979 were found in rural area and the remain 3983 in urban area of Ethiopia((FCA), 2011;2016).Despite the increase in number of SACCOs for the last five year, the multidimensional aspects of poverty remains to be a challenge for the community where by global multidimensional poverty index of Ethiopia decline only from 0.562 to 0.537 (4.6\%) and improve 1 rank (i.e 174 out of 185 countries) from year 2011 to 2016. In year 2017 global multidimensional poverty index of rural Ethiopian is still sever (i.e 0.637) and remains to be the challenge for Ethiopia (United Nation Development programme(united Nation Development programme(UNDP), 2016,2017,2018).UNDP works in about 170 countries and territories, helping to achieve the eradication of poverty, and the reduction of inequalities and exclusion. It helps countries to develop policies, leadership skills, partnering abilities, institutional capabilities and build resilience in order to sustain development results (ibid).

Correspondingly, Awabel cooperative organization and promotion office annual report of 2017 showed that in Awabel district there were a total of 22 saving and credit cooperatives around $90.90 \%$ of them were found in rural area. RuSACCOs gave a total amount of birr 76, 9441 saving deposit service, birr 9,083,375.25 loan service, birr 974,066.45 amount of divided income were distributed for rural household member's. However, the multidimensional poverty status of rural area of Ethiopia including Awabel district severs as clearly stated above. In view of the above statistical facts, research is necessary to analyze the impact of saving and credit cooperative financial service on multidimensional poverty status of beneficial households and compare to that of non-beneficial households in Awabel district.

\subsection{Objectives of the Study}

\subsubsection{General objective of the study}

The general objective of the study is to investigate the impact of saving and credit cooperative on multidimensional poverty status of rural households through providing financial service in Awabel district.

\subsubsection{The specific objectives of the study}

- To investigate determinants of multidimensional poverty status of rural households in Awabel district.

- To examine the impact of saving and credit cooperative on multidimensional poverty status of rural households of Awabel district.

- To identify the dimension of rural household poverty affected by saving and credit cooperatives in Awabel district.

\section{RESEARCH METHODOLOGY}

\subsection{Research Design}

The study was conducted in Awabel district which is situated in East Gojjam administrative zone of Amhara regional state .It is surrounded by Gozamen district in the west, Debaye Telategen district in the in the north, Basoliben district and Abaye Gorge and Oromia region in the south ,Dejen District in the East. The town of the district is so called Lumama, it fars $259 \mathrm{Km}$ from Addis Abeba and $360 \mathrm{Km}$ from state city Bahir dar and $40 \mathrm{Km}$ from zonal city Debre Markos.

Financial service provided by RuSACCO for their member is quantifiable in birr and at the same time its impact on multidimensional poverty status of household is quantifiable hence, the study used quantitative research approach and descriptive research design. 


\subsection{Data types, sources and methods of data collection}

The study employed primary data. Primary data is chosen to get more reliable, complete, meaning full, accurate and adequate information which is suitable to the object and purpose of investigation. Based on time horizon, the study is employed cross sectional data due to the absence of recorded data.

\subsection{Sampling Techniques and sample size determination}

The study used multistage methods of probabilistic sampling techniques. The population refers of the study were all household members of RuSACCOs service Beneficial's. The sampling frame were all the list of RuSACCOs service Beneficial's in the seven selected RuSACCOs who were a member in Awabel district before 2018. The sample size is estimated as:

$\mathrm{n}=\frac{N}{1+N\left(e^{2}\right)}$, Where; $\mathrm{N}=$ is population size, $\mathrm{n}=$ is sample size and; e $=$ is marginal error usually e $5 \%$ is usually accepted error( (Yamane, 1967).

$\mathrm{n}=\frac{4,675}{1+4,675\left(0.05^{2}\right)}, \mathrm{n}=368$.

380 households are used as part of the sample size including 5\% non-response. 190 of them were members of RuSACCO and the remaining 190 were from non-members.

\subsection{Methods of Data Analysis and presentation}

The study used both descriptive statistics, and inferential statistics to analyze quantitative data. The descriptive statistic was summarized using average, minimum, maximum and percentage. The data is presented in the form of multipurpose table. For inferential statistics binary logit models is permitted to identify determinants of multidimensional status of rural households. Additionally, propensity score matching model is used to show the impact of rural saving and credit cooperative financial service on multidimensional poverty reduction.

\subsection{Variable Selection and Model Specification}

Mo:-multidimensional poverty status of each household as dummy dependent variable or outcome variable it can be labeled as poor 1 , other wise 0 . The cut of is 0.33 (OPHI, 2017). It consists of health, education and standard of living dimension with ten indicators

adltedu:- Education Indicator - Years of Schooling, dummy variable $(0=\mathrm{ND}, 1=\mathrm{D})$

childedu:-Education Indicator - School attendance, dummy variable $(0=\mathrm{ND}, 1=\mathrm{D})$

nutrdep:-Health Indicator - Adult malnutrition $(0=\mathrm{ND}, 1=\mathrm{D})$ dummy variable, nutritional status is taken from the computation by using direct calorie intake of households. If the household takes less than the standard per capital nutritional requirement 2,100 calorie per adult per day set by the Ethiopian government the household is deprived, otherwise non- deprived.

childmor:-Health Indicator - Child Mortality, dummy variable $(0=\mathrm{ND}, 1=\mathrm{D})$

floordep:-Standard of Living Indicator - Flooring, dummy variable $(0=\mathrm{ND}, 1=\mathrm{D})$

sandep:-Standard of Living Indicator - improved sanitation $(0=\mathrm{ND}, 1=\mathrm{D})$

wadep:-Standard of Living Indicator - Access for clean water, dummy variable $(0=\mathrm{ND}, 1=\mathrm{D})$ given that less than 30 minute walk fetch and come to home.

enrdep:-Standard of Living Indicator - Cooking Fuel, dummy variable $(0=\mathrm{ND}, 1=\mathrm{D})$

elcdep:-Standard of Living Indicator - Electricity, dummy variable $(0=\mathrm{ND}, 1=\mathrm{D})$

asdep:-Standard of Living Indicator - Assets, dummy variable $(0=\mathrm{ND}, 1=\mathrm{D})$. The weight of the above three dimensions and ten indicators will be adopted from OPHI 2017 in customized way (the detail methodology is similar with page 18 of literature review).

copms: rural saving and credit cooperative membership status, dummy variable dependent variable for logit model (member 1, and other wise 0 ) and treatment independent variable for impact model

Agro ecological zone the household is living (agrozone:-(1=Woynadega zone, 2=Kolla zone, $3=$ Dega zone). Household family size (hhsize):- It is a continuous variable measured by the adult equivalence unit of the household members.

Age of household head (age) and age squared:- It is a continuous variable which is measured by year.

Sex of household head (sex):- It is a dummy variable indicating the male or female of a household head. It takes value one if it is male and zero otherwise.

Religious status of household heads (relg):- It is dummy variable 1 for Christian and other wise 0.

Education status of a household head (eduhh):- This is a categorical variable which stands for educational status of the household head measured in level of schooling completed. It takes zero for illiterate household heads, 1 for primary education completed, 2 for secondary education completed and 3 for tertiary education completed.

Marital status of household head (marts):- It is categorical variable expressing the marital status of a household head. It takes 1 for single household heads, 2 for married household heads, 3 for divorced household heads and 4 for widowed household heads. 
Size of cultivated Land holding (land):- It is continues variable which is measured is hectares of land cultivated owned by the households.

Total Livestock unit (tlu):- It is the amount of livestock measured in tropical livestock unit (Aklilu F., 2013).

Dependency ratio (dr):-It is measured by the ratio of;

$$
=\frac{\text { people of age }(14 \text { and below }+ \text { age above } 65)}{\text { people above age of } 14 \text { and below age of } 65)}
$$

Experience of household head in agricultural activity (agrexp):- It is continues variable which can be measured by the amount of year spent by household heads.

Accessibility of road all year (accroad):- It is dummy variable if yes 1, otherwise, 0 .

Access for agricultural extension service (agrext):- It is measured by frequency of extension contact in a day per month

Drought:-It dummy variable if yes 1 , otherwise, 0 .

Off-farm and non-farm income:- continuous variable measured by the amount of income received from offfarm income source in birr in a given year. To measure the impact of RuSACCO financial service on multidimensional poverty status of rural households, the researchers have an outcome variable of multidimensional poverty status of each rural house hold and its three dimensions.

\section{RESULT AND DISCUSSION}

\subsubsection{Multidimensional poverty status of respondents}

The finding of the study shows 93.95 percent of rural peoples are multidimensional poor. in the study area . According to the intensity of poverty indicator (A) in Awabel district on average the poor people's are deprived $61.75 \%$ of the weighted indicators. Additionally, the adjusted multidimensional deprivation head count (Mo) shows that the society is in acute poverty i.e the society is deprived in 58.01 percent of the total potential deprivation it could experience over all. They are deprived at least either all indicator of a single dimensions or a combination across dimensions such as being in a household with a malnourished person, no electricity, no access for clean water, shared sanitation. The result is relatively lower than the multidimensional poverty status of rural area of Ethiopia Mo 0.637, H 96.30\% and A 66.20\%of poverty status ((OPHI), 2017).

Table 3-1: Contribution of indicator to multidimensional poverty status

\begin{tabular}{ll}
\hline Indicators of deprivation & Total \\
\hline Adult education & 0.1489 \\
Child education & 0.1421 \\
Child mortality & 0.1535 \\
Nutrition & 0.1535 \\
Sanitation & 0.1550 \\
Energy & 0.08619 \\
Clean water & 0.05595 \\
Floor & 0.08997 \\
Assets & 0.05595 \\
Electric city & 0.06981 \\
\hline
\end{tabular}

Source: own survey, 2018 .

From the above table the highest share of multidimensional poverty comes from sanitation, nutrition, and child mortality which means that the households either they use shared toilet, or excrete on the field which might raise the expansion of containable disease and increase child mortality and higher medication cost which in turn reduce malnourishment or calories per day would be less than 2100 calories. Moreover, adult education, floor, energy, electric city are the contributor for multidimensional poverty respectively but poor access for clean water and asset are is likely to negatively affect household health and hence household wellbeing.

Table 3-2: Contribution of each domain to multidimensional poverty

Source: own survey, 2018.

\begin{tabular}{ll}
\hline Dimension of deprivation & Total \\
\hline Education & 0.2911 \\
Heath & 0.3085 \\
Standard of living & 0.4005 \\
\hline Total & 1 \\
\hline
\end{tabular}

The above table shows that the highest contribution to multidimensional poverty index is standard of living in Awabel district which accounts about $40.05 \%$ followed by health (30.85\%) and education (29.11\%). The data shows that standard of living is under harsh condition in the sample of rural households. The finding of the study confirm with (Andualem, 2016).In poor country the standard of living is the highest contributor to multidimensional poverty status of households. 


\subsubsection{Decomposition of Multidimensional Poverty status of Respondent Households}

Multidimensional poverty can be decomposed by dimensions, indicators and with different groups by (kebela) or sub-district to understand the deprivation poverty level among sub -district.

3.2.2.1 Decomposition of multidimensional poverty by membership status

Table 3-3: Decomposition of multidimensional poverty byRuSACCos membership status

\begin{tabular}{lll}
\hline & RuSACCO members & RuSACCO non-members \\
\hline H & 0.9259 & 0.9529 \\
A & 0.5854 & 0.6484 \\
Mo & 0.542 & 0.6178
\end{tabular}

Pearson $\operatorname{chi} 2(15)=29.2614 \operatorname{Pr}=0.000$

Source: own survey, 2018

The above that show that in Awabel district $95.29 \%$ of rural saving and credit cooperative non-members and $92.59 \%$ percent of member peoples are multidimensional poor. In Awabel district the intensity of poverty for RUSACCO non members and members were $64.84 \%$ and $50.54 \%$ respectively. The multidimensional poverty indicator for members and non-members (Mo) shows that the society is in acute poverty i.e the nonmember's society is deprived in 61.78 percent and the member's society was deprived $54.20 \%$ of the total potential deprivation it could experience over all. The chi2 test shows that there is an association between multidimensional poverty status and RuSACCO membership status at $1 \%$ significance level and hence, it is significant to multidimensional poverty status.

They are deprived at least either all indicator of a single dimensions or a combination across dimensions such as being in a household with a malnourished person, no electricity, no access for clean water, shared sanitation but the status of poverty is different between members and nonmembers due to the availability of RuSACCO financial services which allow to them more engagement in economic activities.

Table 3-4: Contribution of indicator to poverty by membership status

\begin{tabular}{lll}
\hline Indicators of deprivation & RuSACCO members & RuSACCO Nonmembers \\
\hline Adult education & 0.1368 & 0.1609 \\
child education & 0.1338 & 0.1504 \\
Nutrition & 0.1444 & 0.1625 \\
Child mortality & 0.1353 & 0.1745 \\
Floor & 0.08867 & 0.09125 \\
Sanitation & 0.0435 & 0.04162 \\
Clean water & 0.04712 & 0.06468 \\
Energy & 0.08513 & 0.08724 \\
Electricity & 0.06891 & 0.0707 \\
Asset & 0.05067 & 0.06117 \\
\hline Total & 0.9344 & 1.065 \\
\hline
\end{tabular}

Source: own survey 2018.

The highest share of multidimensional poverty status for non-members was child mortality, adult education, nutrition, child educations, floor, energy ,clean water, electricity and asset acquisition respectively, which means that when nonmembers had no financial availability from RuSACCO's, the use less input for production ,low budget allocation for health which may rise child death .

The contribution of indicators to multidimensional poverty index for members comes from nutrition, adult education, child mortality, child education, floor, energy, clean water, electricity and asset acquisition respectively. The effect is highly observed in child mortality, adult education, and nutrition respectively but the being the members of RUSACCO may result shortage of time to dig toilet.

In poor country the standard of living is the highest contributor to multidimensional poverty status of households.

Table 3-5: Contribution of domain to poverty status by membership status

\begin{tabular}{lll}
\hline Dimension of deprivation & RuSACCO members & RuSACCO non- members \\
\hline Education & 0.2706 & 0.3114 \\
Health & 0.2797 & 0.3369 \\
Standard of livings & 0.3841 & 0.4167 \\
\hline Total & 0.9344 & 1.065 \\
\hline
\end{tabular}

Source: own survey, 2018

The above table shows that the highest contribution to multidimensional poverty index is standard of living for both members and non members in Awabel district which accounts about $38.41 \%$ for members and $41.67 \%$ for nonmembers.

The second highest contribution domain to poverty status of rural household in the study area is health $(27.97 \%)$ for members and for nonmembers $(33.69 \%$,). 
The third contribution domain to poverty status of rural household is education which accounts $27.06 \%$ for members and $31.14 \%$ for nonmember.

The data shows that standard of living is a serious problem for both in the sample of rural households. The finding of the study confirm with (Andualem, 2016).

\subsection{Econometric result}

Table 4-1: Regression result of the Binary Logit model

\begin{tabular}{lrrr}
\hline Variable & $\mathrm{dy} / \mathrm{dx}$ & $\mathrm{Z}$ & $\mathrm{P}>\mathrm{Z}$ \\
\hline Zone & -0.0021161 & -1.38 & 0.302 \\
Sex & -0.005605 & -0.95 & 0.343 \\
RuSACCOsmembership status * & -0.0420176 & -2.54 & 0.000 \\
Size of cultivated land holding * & -0.0501648 & -3.21 & 0.000 \\
Dependency ratio** & 0.0011985 & 1.99 & 0.032 \\
Agricultural experience ** & -0.0015961 & -2.41 & 0.004 \\
Total livestock unit & 0.0001623 & 0.04 & 0.978 \\
Drought & 0.0025855 & 0.84 & 0.787 \\
Marital status & 0.004002 & 1.08 & 0.279 \\
Religion & -0.0003865 & -0.42 & 0.897 \\
Family size per adult equivalence & 0.0020927 & 0.06 & 0.983 \\
Access for agricultural extension* & -0.04013497 & -2.12 & 0.000 \\
Age of household head & 0.000234 & 0.56 & 0.67 \\
Educational status household head & & & \\
primary education* & & -3.93 \\
Secondary education* & & 0.000 \\
Higher education * & -0.01890 & -3.51 & 0.000 \\
Access for road * & -0.03005 & -3.51 & 0.000 \\
Off farm income* & -0.04373 & 0.000 \\
\hline
\end{tabular}

*,and ** means significance at $1 \%$, and $5 \%$ respectively. Source: own survey, 2018.

Based on the above table prediction on determinates of multidimensional poverty status of rural household in Awabel district can be made as follows.

1) Saving and credit cooperative membership:- Keeping all other factors constant, if a rural household shift from being a nonmember to a member of SACCOs, the average marginal effect shows that, the probability of being multidimensional poor decreases on average by 4.2 percent and statistically significant at 1percent. The explanation is that if the rural household is a member of SACCO which implies more access for financial services which allow them to perform off farm activity such as pity trade, fattening, animal rearing and irrigation, and on farm activity by rise the purchase of agricultural inputs such fertilizer, improved seed, pesticide, insecticide etc. consequently, increase output level, income rise and improve consumption which reduce educational, health and asset deprivation. The result conforms to (Adekola, G. and Dokubo,Chidinma, 2017), (Ahlén, 2012) (Bello, 2010) (Gomina, 2015) and (Prof. LD Sudhakara Babu, 2015)

2) Size of cultivated land holdings:-Keeping all other factors constant, as the size of cultivated landholding of household head increased by one hectare, on average marginal effect, the probability of a households being multidimensional poor goes down by 5 percent and statistically significant at 1 percent. The explanation lies, in one side, when the size of land holding increases, it will allow diversification of crops to reduce risk and uncertainty of agricultural output, rise the application of modern farming as a result crop yield response will rise; on the other side, large cultivated land holding allow to rise total livestock units and their by reduce the multidimensional status of rural households. The finding supported by (Andualem, 2016), (Magnus Andersson, Anders Engvall and Ari Kokko, 2005) and (Teshome, Kebede, Deressa and M. K. Sharma, 2014) .

3) Dependency ratio: - keeping all other things constant, as the amount of dependency ratio increases by one unit, on average marginal effect, the probability of being the multidimensional poor increased by 0.11 percent and statistically significant at 5 percent. The economic justification lies high dependency ratio in the household implies, high burden of food and non-food item with in the 
household which rise education, health and asset deprivation. It confirm with (Tsgay, 2014), (Teshome, Kebede, Deressa and M. K. Sharma, 2014) findings.

4) Access for road:-If rural household shift from being non access for road to access for road, on average marginal effect, the probability of being multidimensional poor will goes dawn by 1.7 percent, keeping all other factors constant and statistically significant at 1 percent. The economic justification is that, when rural household have availability of road through the production year, they could have access for market to sell their crop output as well as livestock and livestock products at competitive price, save their time and their by rise their standard of lings. Moreover, when there is availability of road, it can facilitate the availability of other infrastructure like clean water, telephone, school, heath office etc. and there by improve the poverty status of rural households. It confirm with (Odoyo, 2012), (Katsushi.Ima, 2010) etc.

5) Access for agricultural extension service:-As frequency of agricultural extension service was increased by unit per month, on average marginal effect, the probability of being multidimensional poor goes down by 4 percent, keeping other factors constant and it is significant at 1 percent. The household head that have access for agricultural extension service implies more knowledge for uses of modern technology such as use of improved seed, pesticide and insecticide and hence, which reduce educational, health and asset deprivation. The result confirms to (Andualem, 2016), (Ahlén, 2012) (Gomina, 2015) .

6) The educational status of household head:-The average marginal effect of education status of household head, keeping other factors constant, shows that for each additional educational level from illiterate to literate, primary to secondary and from secondary to higher education there is an average of $1.89 \%, 3 \%$ and $4.3 \%$ reduction in the probability of a rural household of being in multidimensional poor.

7) Experiences of household head on agriculture activity:-Keeping all other things constant, as the year of engagements or experience in agricultural activity increases by one year, on average marginal effect, the probability of being multidimensional poor goes dawn by 0.159 percent and statistically significant at 5 percent. The economic justification that rural household having many years of experience on crop production and animal rearing practice, it can easily identify the diseases, risk period, harvest period and improve household management skill which in turn reduce the long run average cost of production by learning by doing with time and their by improve the poverty status of rural households .the result is limited with this regard.

\subsubsection{The impact RuSACCOs on poverty status of rural households' in Awabel district}

Table 4-2: The average treatment effect on treated poverty status of households

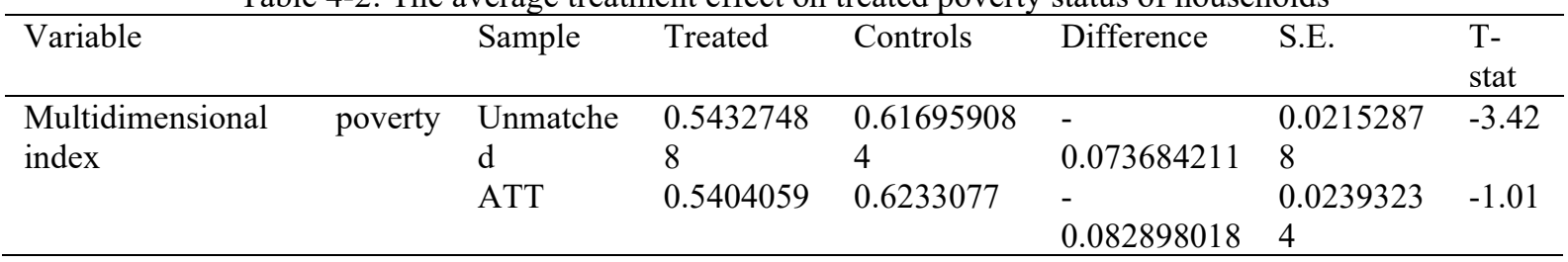

Source: own survey, 2018.

The above output shows that, rural household get a significant negative treatment effect on their multidimensional poverty index i.e(-0.082898018) difference is brought due to rural saving and credit cooperative finical service intervention for members than nonmembers . Alternatively, rural household of the treatment group, the treatment has reduced their multidimensional poverty index by 0.082898018 on average

The explanation is that rural saving and credit cooperative provide saving deposit, loan and dividend income service in Awabel district as clearly stated in descriptive part of the study. Hence, the members use this financial service for summer season crop production, pity trade, animal fattening, current consumption, irrigation and horticulture activity respectively which in turn leads to reduction multidimensional status of household. This finding confirms to (Tsgay, 2014), (Adekola, G. and Dokubo,Chidinma , 2017) and (Eleuter Atilio Kihwele and Raphael Gwahula , 2015). Unlike the above researcher findings (Churk, 2015 )finding revealed that, SACCOS have played minimal role towards promoting rural livelihoods in the study area, the feature that made poverty situation to persist to the community members due to higher interest rate charge on members and other constraints observed in rural saving and credit cooperatives .

It is clearly known that poverty had three dimension, education deprivation, health deprivation and standard of living deprivation. The researcher tries to see the impact of RuSACCO financial service on the three dimensions.

1) Standard of Living Dimension:-It consists of six indicators such as asset acquisition, floor, cooking fuel, access for clean water, sanitation and electricity jointly. 
Table 4-3:the average treatment effect on treated standard of living dimensions

\begin{tabular}{llrrrrr}
\hline Variable & Sample & \multicolumn{1}{c}{ Treated } & \multicolumn{1}{l}{ Controls } & Difference & \multicolumn{1}{l}{ S.E. } & \multicolumn{1}{l}{ T-stat } \\
\hline Standard of living & Unmatched & 0.237263 & 0.250821 & -0.01356 & 0.006459 & -2.1 \\
& ATT & 0.236578 & 0.251779 & -0.0152 & 0.00656 & -1.32 \\
\hline
\end{tabular}

Source: own survey result, 2018.

As clearly shown in the table above the impact of RuSACCO financial service for standard of living is statistically insignificant that the individual of the treatment group, the treatment has not reduced standard of living deprivation by -0.0152 on average (see, annex table 14). The explanation is that the rural household use the financial service for the purchase of radio, television, and car and creates access for electricity, other assets and few energy sources which is a means for future production as well as raises their current consumption and their by reduce the standard of living dimension of poverty

2) Educational Dimension:-It consists of child education and adult education indicators of poverty. Table 4-4: the average treatment effect on treated educational dimension

\begin{tabular}{lllllll}
\hline Variable & Sample & Treated & Controls & Difference & S.E. & T-stat \\
\hline Education & Unmatched & 0.164363254 & 0.181942101 & -0.017578947 & 0.012662 & -1.39 \\
& ATT & 0.164335102 & 0.183251007 & -0.018915905 & 0.014219 & 1.05 \\
\hline
\end{tabular}

Source: own survey result, 2018.

The output shows that for the individual of the treated group, the treatment has reduced the educational deprivation by -0.018915905 on average (see, annex table12 for details). The explanation is that the availability of financial service allow the members to cover the costs of education and their by rise year of schooling and school attendance and their by reduce child education and adult education indicator of multidimensional poverty status of rural households.

3) Health Dimension:-It consists of two indicators of poverty i.e nutrition and child mortality. The effect of RuSACCO financial service on it can be seen below.

Table 4-5: The average treatment effect on treated health dimension

\begin{tabular}{lllllll}
\hline Variable & Sample & Treated & Controls & Difference & S.E. & T-stat \\
\hline Health & Unmatched & 0.162605259 & 0.196005258 & -0.0333999999 & 0.118934445 & -2.81 \\
& ATT & 0.162558506 & 0.198801281 & -0.036242775 & 0.01322415 & -1.56 \\
\hline
\end{tabular}

Source: own survey result, 2018.

The output shows that for the households of the treated group, the treatment has reduced the health dimension of poverty by -0.036242775 on average. The explanation is that the prevailing financial availability for members allows reducing child death and increasing expenditure on food, which in turn prevent infectious disease as well as improving nutritional status of children's and their by reduce the health dimension of poverty . The finding confirms (Nuredin Mohammed, Byeong Wan Le, 2015).For the validity of the average treatment effect.

\section{4: SUMMARY, CONCLUSION AND RECOMMENDATION \\ 4.1 Summary and conclusion}

The descriptive statistics shows that the level of multidimensional poverty in Awabel district is severed, that is 93.95 percent of peoples are multidimensional poor, the intensity of poverty is 61.75 percent and 58.01 percent of the total potential deprivation it could experience over all. The finding revealed that multidimensional poverty status of rural household is negative and significantly relationship between RuSACCO membership status, size of cultivated landholdings, access for agricultural extension service, and access for road. Moreover, there was a negative relationship between experience of household head on agricultural activity, the risen in educational status of household head from illiterate to literate, primary to secondary and from secondary to higher education goes dawn multidimensional poverty status It is also found that, there were positive relationship between, multidimensional poverty status of rural households and dependency ratio in Awabel district.

In is also found that saving and credit cooperatives financial service reduced multidimensional poverty index by 0.082898018 for members compare to that of nonmembers . This finding confirms to (Odoyo, 2012),(Obadia, 2014), (Oluyombo, 2013) and (Adekola, G. and Dokubo,Chidinma , 2017)etc. In addition the RuSACCOs financial service has reduced health dimension of poverty by 0.036242775 , the educational dimension of poverty by 0.018915905 , and standard of living dimension of poverty by 0.0152 on average for member rural households compare to that of non-members respectively.

\subsection{Recommendation}

Based on this research finding, the researcher forwards the following recommendations;

- Saving and credit cooperatives membership status negatively affect the multidimensional poverty status of rural household and hence, the government should give special attention for organization and promotion of cooperative and improve the awareness level of farmers about RuSACCO. Additionally, the rural saving and credit expert should also advice members of RuSACCO to use 
their financial service more on health, education and standard of living respectively.

- Size of cultivated land holding is negatively and significantly related with poverty indicating larger cultivated and holding goes down multidimensional poverty status of rural household, through securing food need and earning substantial on farm income hence, but size of land holding is saturated in Awabel district the government should shift grazing land into cultivable land as well as increasing production per unit of cultivated land holdings.

- Multidimensional poverty status of rural household is significantly influenced by educational status of household; hence, the government should have to work hard to bring literate farmers especially, to secondary and higher education level.

- The government and other concerned bodies work against reducing young age dependency, so as to reduce the multidimensional poverty status of rural households.

- The government and other concerned bodies should give special attention to rising road accessibility of rural households and their by improve the multidimensional poverty status of rural households.

- The government should raise the accessibility of agricultural extension workers, so as to improve multidimensional poverty status.

- The government should raise experience sharing among farmers to improve the multidimensional status of rural household's members.

\section{References}

Africa Confederation of Cooperative Savings and Credit Association (ACCOSACA). (1970) Retrieved January 24, 1018, from Google (https://www.linkedin.com/in/accosca-africa (accessed on january, 2018).

Awabel woreda Cooperative organization and promotion office (AWCOPO),(2017). Basic document.Centarl Statistics Agency (CSA), (2017). Population survey.

East Gojjam Zone Cooperative Organization and Promotion Office (EGZCOPBO), . (2017). Basic document .

Federal Cooperative Agency (FCA). (2011;2016). Annual report. Addis Abeba ,Ethiopia: Federal cooperative Agency of Ethiopia.

Federal Democratic Republic of Ethiopia (FDRE) cooprative proclamation no 147/98, F. d. (1998,2016). Cooperative proclamation no Fedarl Democratic Republic of Ethiopia; 147/98, 985/2016. Addis Abeba ,Ethiopia: Nigarite Gazeta.

World Bank (WB). (2007). Providing financial services in rural areas a fresh look at financial cooperatives,. Washington DC: the agriculture and rural development department:

Federal democartic Republic of Ethiopia (FDRE)Cooperative Proclamation no 147/1998. (1998, Decembers 29th). Addid Abeba, addis abeba, ethiopia: Federal Nigrit Gazata.

Oxford Poverty and Human Development Initiative (OPHI).(2017). "Ethiopia Country Briefing”, Multidimensional Poverty Index Data bank. OPHI, univesity of Oxfored : Oxford Department of International Development.

Adekola, G. (PhD) and Dokubo,Chidinma (PhD). (2017, march). Co-OperativeSocieties and Poverty Reduction AmongMembers for CommunityDevelopment in Rivers State,Nigeria. European Scientific Journa, pp. vol.13,No.8 ISSN:1857 - 7881(Print)e - ISSN1857- 7431.

Ahlén, M. (2012). A field study assessing the impacts of SACCOS and VICOBA in Babati district, Tanzania. Södertörn University School of Life Sciences.

Aklilu, F. (2013). Assessing the Impact of Productive Safety Net Program on Asset Building and Sustainable Land Management Practices: a Cross Sectional Analysis from Eastern Hararghe. Mekele University; Mekele.

Aklilu, F. (2013). Assesing the impact of productivity safety net progeram on Asset Bulding and sustanable Land management practice .

Andualem, G. (2016). A panel Mutidimesional Estiamtion for Ethiopia. University of Milan :Italy.

Antawi, B. D. (2015). Microfinace and poverty reduction in Gahana : Evidance from the Dorma area teachers cooperative Union in Dorma Muncipality Brong Ahafo.

Anyanwu, J. C. (2013, september ). Marital Status, Household Size and Poverty in Nigeria:Evidence from the 2009/2010 Survey Data. Working papar series No 180. Africa development bank group .

Arane Thavaneswaran and Lisa Lix. (April 22/2008). Propensity Score Matching in Observational Studies. Manitoba Centre for Health Policy.

Asad K.Ghalib, I. M. (2011). The impact of microfinace and its role in easing poverty rural households :estimation from pakistan . Research Institute for Economics and bussiness Adminstartion, Kobe Universoity .

Understanding the Determinants of Poverty. Poverty Manual. (August 8, 2005 ). All, JH Revision, (pp. pp 124 218.).

Aziza, G. (2013). The role of microfinance in poverty reduction: Master thesis. Addis Abeba : Addis Abeba University . 
Bank(WB), W. (2007). World Bank (2007).Providing financial services in rural areas a fresh look at financial cooperatives. Washington DC.: the agriculture and rural development department.

Bello, D. A. (2010, june). The Role of Cooperative Societies in Economic Development. Munich Personal RePEc Archiv Ahmadu Bello University, Zaria-Nigeria.

C.R.Kothari. (2004). Research Methodology methods and techniques 2 nd revised edition. New Delhi: New Age International publisher.

Churk, J. P. ( 2015 ). Contributions of Savings and Credit Cooperative Society on Improving Rural Livelihood in Makungu ward Iringa, Tanzania. Proceedings of the Second European Academic Research Conference on Global Business, Economics, Finance (pp. vol.13,No.8). Zurich-Switzerland: European Scientific Journal.

Claessens, S. \&. (2007). Financial sector development and the millennium development goals. (No. 89) . World Bank Publications.

Clement O. Olando( PhD), M. O. (2012). Financial Practice as a Determinant of Growth of Savings and Credit Co-Operative Societies' Wealth. International Journal of Business and Social Science, vol. 3 No. 24.

Cohen,J.,Cohen,P.,West,S.and Aiken, L. ,.(2003). Applied multiple regression/correlation analysis for the behavioral science, third edition. Mahwan, New Jersey, Lawrance Erlbaum Associates.

Commission United Nations Human Rights commission (UNHRC). (1202). poverty startegyRetrievedFebruary10,2018, http://www.ohchr.org/Documents/Publications/Poverty Strategies,

Dean Karlan, Beniamino Savonitto, Bram Thuysbaert, and Christopher Udry. (2017, march 21). google shollar. Retrieved January 23, 2018, from google: https://doi.org/10.1073/pnas.1611520114

Dr.MuthyaluMeniga. (2014). A Study on Challenges and Opportunities of Rural Savings andCredit Cooperatives (RUSACCOs). European Journal of Business and Management, Vol.6, No.20.

Eleuter Atilio Kihwele and Raphael Gwahula (PhD). (2015). Impact of Saving and Credit Cooperative Societies in Poverty Reduction. Empirical Evidence from Tanzania. European Journal of Business and Managemen, pp. Vol.7, No.23.

Federal cooeprative Agency of ethiopia (FCAE). (2016). Working manual. Addis Abeba .Ethiopia: Federal coopeartive agency.

Federal Cooperative Agency of Ethiopia(FCAE). (2004). Basic Document . Addis Abeba ,Ethiopia : Federal coopertive Agency .

Foster and Sabina Alkire and James, F. (2011). Understandings and Misunderstandings of Multidimensional Poverty measurement. Sabina Alkire and James Foster (2011).Understandings and Misunderstandings of Multidimensional Oxford Department of International Development: University of oxford.

Garson. (2012).Testing statistical assumptions. Retrieved january 28, 2018, from http://www.statisticalassociates.com/assumptions.pdf: http://www.statisticalassociates.com

Gomina, A. A. (2015). Impact of Savings and Credit Cooperative Societies on Poverty Status of Crop Farmers in Niger State, Nigeria. Academic Research Journal of Agricultural Science and Research, 142-150.

Gujarati. (2004). Basic econometrics 4th edtion. New york: McGraw-Hill campanies.

IFAD. (2011). working Document .

John Sumelius,Shimelles Tenaw,Stefan Bäckman,Faustine Bee,Suleman Chambo,Gervas MachimuNeema Kumburu,. (2013). Cooperatives as a Tool for Poverty Reduction and Promoting Business in Tanzania. (p. 65). Helsinki.

Katsushi.Ima, T. ,. (2010). Micro fiancé and house hold poverty reduction in India. Research Institute for Economics and Business Administration,Kobe University. .

Kifela, T. (2015). Savings and Credit Cooperatives in Ethiopia: Development, Challenges andprposed intervation. International Journal of Cooperative Studies, Vol. 4, No. 1, 2015, 1-8.

Kifle, T. (2015). Savings and Credit Cooperatives in Ethiopia: Development, Challenges and Proposed Intervention. International Journal of cooperatives studies, Vol. 4, No. 1, 2015, 1-8.

M.L.Jhingan. (2007).The economics of development and planning, 39 the dition,. Delihi.: Verinda publications.

Magnus Andersson, Anders Engvall and Ari Kokko. (2005). determinats of poverty in LAO PDR. Lao PDR: Sida 2006 Department for Policy and Methodolog.

Melania D.Kawi and Justin K.Urassa. (2015, April). the contribution of saving and credit cooperative socites to income poverty reduction : A case study of Mbozi district Tanzania. Journal of african development, pp. vol 7(4) pp 99-111.

Nuredin Mohammed, Byeong Wan Le. (2015). Role of Cooperatives in Rural Development, the Caseof the Case of South Nations Nationalities and People. Science Journal of Business and Management., Vol. 3, No. 4, pp. $102-108$

Obadia, M. (2014). Contributions of Saving and Credit Cooperative Societies(SACCOs) on the growth sustenance of smallbusinesses in Tanzania: The case of Mbeya city. Masters of Business Admistration. Tanzania.

National Convention on wards Poverty Alleviationand Social Development :The Role of MFIs. (oct,2014). No.10. Dahaka: PKSF Auditorium, PKSF Bhaban. 
Odoyo, O. S. (2012). Impact of SACCOS in alleviation of poverty in Kenya: a case of kisumu county. Master of Business Administration thesis.

Oluoch, M. A. (2016). Determinants of Savings Mobilization of Saccos in Kenya . THE International Journal of Bussiness and Managemnet, vol 4(4).

Oluyombo, O. (2013). The Role of Co-operative Loans in Rural Finance: Evidence from Ogun State, Nigeria. Journal of Co-operative Studies, , 5-15.

Prof. LD Sudhakara Babu. (2015). Determinants of Poverty in Rural Tigray: Ethiopia . International Journal of Science and Research, 822-828.

Rosenbaum, P. R., \& Rubin, D. B. (April .,1983). The Central Role of the Propensity Score in Observational Studies for Causal effetcs . Biometrika Trust, pp 41-55.

Semere, G. (April 2008). Dimensions and Determinants of Rural Household Poverty. The Case of Eastern Zone, Tigray National Regional State. The CaM.sc Thesis in Agricultural Economics, Alemaya University.

Sharma, T. K. (2014). Determinant of Poverty in Ethiopia. Ethiopian Journal of Economics, 114-130.

Solomon Abadi Dirar, T. B. (2017). Financial product development and members' voluntary saving behavior in saving and creditcooperatives in Tigray: A case study in Endamohoni Woreda . Cogent Economics \& Finance.

Spangenberg, S. (2015). Hermann Schulze-Delitzsch: The Cooperative Idea in German Liberal. Global Journal of Human-social Science Global Journals Inc. (USA) publisher, Volume 15 Issue 1 Version 1.0 .

Teshome Kebede Deressa and M. K. Sharma. (2014). Determinant of Poverty in Ethiopia. Addis Ababa University, Addis Ababa, Ethiopia, 114-130.

Tsgay, M. (2014, January). Household level Analysis of Rural poverty: the case of Gozamn district of East Gojjam Zone, Ethiopia. Msc thesis Haromaya University. Ethiopia.

(n.d.). Understanding the Determinants of Poverty. In Poverty Manual, All, JH Revision of August 8, 2005 (pp. 136-218).

United Nation Development programme(UNDP).(2016;2017\&2018). Mutidimenstional poverty index of coutries. world bank.

World-Council-of-Credit Unions(WOCCU)(2017). Retrieved January1, 2018, from http://www.uwcc.wisc.edu/icic/orgs/copac/member/WOCCU-World-Council-of-Credit-Unions1/BriefHistory-of-WOCCU1.html .

Yamane, T. (1967). Statistics: an Introductory Analysis, 2nd Edition. New York. 